\title{
Effects of Vegetation Cover and Land Use Changes on Soil Erosion in Kalaya Watershed (North Western Morocco)
}

\author{
Khadija Ben Hamman Lech-hab ${ }^{*}$, Lamiae Khali Issa1, Ahmed Raissouni', \\ Abdelkrim El Arrim1', Abdelghani Afailal Tribak', Rachid Moussadek ${ }^{2}$ \\ ${ }^{1}$ Department of Earth Sciences, Laboratory of Environment, Oceanology and Natural Resources, Faculty of \\ Sciences and Technologies, Abdelmalek Essaâdi University, Tangier, Morrocco \\ ${ }^{2}$ Unit of Environmental Research and Conservation of Natural Resources, Laboratory of Mapping, GIS and \\ Remote Sensing, Regional Centre of Agricultural Research, INRA, Rabat, Morrocco \\ Email: "achhab.khadija@hotmail.fr
}

Received 21 October 2015; accepted 26 December 2015; published 29 December 2015

Copyright (C) 2015 by authors and Scientific Research Publishing Inc.

This work is licensed under the Creative Commons Attribution International License (CC BY). http://creativecommons.org/licenses/by/4.0/

(c) (i) Open Access

\begin{abstract}
Vegetation cover degradation is still a very common problem in many parts of Morocco; moreover, it affects straight up the amount of the annual soil loss rate. The analytical approach used in this study, respectively, includes remote sensing techniques, application of USLE (Universal Soil Loss Equation) and overlay analysis in a raster Geographic Information System (GIS) environment, employing available information on the region covering the Kalaya catchment. Thus, this procedure allowed the calculation of the NDVI (Normalized Difference Vegetation Index), the execution of two types of classification (unsupervised and supervised) for 1999 and 2010 imagery and eventually the prediction of soil erosion risk in the watershed in question. The main outcome was the production of multidate vegetation cover maps, land use maps and soil loss risk maps. The overlay of two maps allowed us to highlight the changes occurred in this area, which evidence the high anthropogenic impact on the dynamics of land use and vegetation cover. The results suggest that the outputs of this study can be used for predicting rate of soil loss, which varied from 31.68 $\mathrm{t} \cdot \mathrm{ha}^{-1} \cdot \mathrm{yr}^{-1}$ in 1999 to $34.74 \mathrm{t} \cdot \mathrm{ha}^{-1} \cdot \mathrm{yr}^{-1}$ in 2010.
\end{abstract}

\section{Keywords}

Remote Sensing, GIS, Kalaya Catchment, Land Use, USLE

\footnotetext{
${ }^{*}$ Corresponding author.
}

How to cite this paper: Ben Hamman Lech-hab, K., Issa, L.K., Raissouni, A., El Arrim, A., Tribak, A.A. and Moussadek, R. (2015) Effects of Vegetation Cover and Land Use Changes on Soil Erosion in Kalaya Watershed (North Western Morocco). International Journal of Geosciences, 6, 1353-1366. http://dx.doi.org/10.4236/ijg.2015.612107 


\section{Introduction}

With vegetation covering about $20 \%$ of our planet, it's not surprising that nearly every aspect of our lives is tied into the vegetation and land cover that surround us. These latter play a vital role in maintaining the earth's energy balance and considered as a key component of our ecosystem. The management and the modification of natural environment, including vegetation cover, into built environment is refers to as land use. Actually, the land use can be defined, properly, as "the arrangements, activities and inputs people undertake in a certain land cover type to produce, change or maintain it” [1] [2].

As a side effect and negative one of the population growth, technological advances, and economic improvement, vegetation and land degradation have reached striking and shocking rates on our planet. Currently, forest fires, deforestation, uncontrolled urbanization, pollution and agricultural intensification threaten land sustainability as well as human life itself [3]. For instance, development of new farmland often competes with the preservation of wetlands or forest ecosystems; urbanization and industrialization may irreversibly convert valuable agricultural land [4].

In response to the excessive demand of society's for more development and more production, to meet its consumption and to fulfill its consumer's demands and wants, major modification and conversion of land cover occur. However, with a growing awareness of the importance of these environment components, various acts are made in order to preserve, convert and manage natural ecosystems for future generation's needs [5]. Sadly, even with all this measures taken to reduce this phenomenon, the damages already caused to the vegetation and land cover has launched in multiple areas in the world the issue of erosion.

Water erosion is a widespread phenomenon, influenced generally by a considerable number of factors including climate, soil, topography, land use and types of land management. The influence of land use and vegetation changes on soil erosion is highly variable and depends on the density of vegetation cover and vegetation morphology [6].

The Mediterranean region is known as one of the most zones threatened by erosion, due to long dry periods followed by heavy bursts of erosive rain, falling on steep slopes with fragile soils. Therefore, many of these areas have reached critical environmental conditions that in some cases are irreparable [7]. Land cover changes, often due to forest fires, intensive grazing, and changes of agricultural patterns, not to mention urban growth have been contributing to Mediterranean land degradation.

Several studies have shown that there were significant land use changes causing the elevation of aridity accelerating water erosion in certain Mediterranean regions during the second half of the 20th century [8]. For instance, De Noni (2002) [9] reported a serious trend of land degradation resulting from the expansion of cultivation at the expense of natural forests, not to mention the climatic changes and ragged topography that characterized lands in Morocco. Under those circumstances, soil become more subjected to erosion placing Morocco among the countries the most sensitive to erosion. As a matter of fact, even if Morocco's economic development relay mostly on its agriculture activity, agriculture lands covers only 9.2 million from a total land area of 71.085 million hectares. However, pastures, rangelands and deserts cover the largest area with 46 million ha, and finally comes forests covering only 5.8 million ha [10].

Morocco is one of the Mediterranean countries that have always suffered from land degradation and mismanagement. In some region in Morocco, about $70 \%$ of the land is collectively used by local tribes and communities, and land use conflicts over access to grazing areas and water are regular features, seriously contributing to continual and often intensive degradation of the land. Land degradation is an environmental issue and, at the same time, a development issue. Sustainable land management is essential to both combating degradation of ecosystems and improving human well-being [11]. Actually, a study conducted by FAO in 1977 [12] estimated that across Morocco 12.5 million hectares of farmland and rangelands are actually threatened by erosion, and if conservation measures were not taking, the other two third of cultivated land will in turn be attacked. Another FAO study (1990) [13] revealed that the situation continues to deteriorate and becomes more and more critical, and evaluate that almost $40 \%$ of land in Morocco are affected by erosion.

In order to address this issues, imperative measurement to the land where soil degradation and erosion risks are most intense should be taking. To put it other way, land conservation management must be established within a program of sustainable agricultural development and throughout researches.

The overall aim of this work include mapping vegetation cover, land use and soil erosion using the integration of remote sensing and GIS in Kalaya watershed. The methodology used helped us to highlight areas that are at 
potential risk of extensive vegetation cover and land degradation and provide information on the estimated value of annual soil loss in the targeted watershed. With regard to assess erosion loss, different models are widely developed, however, to achieve the above mentioned aim, the Universal Soil Loss Equation (USLE) has been used in this context since it's considered to be the efficient soil erosion model for Mediterranean regions. This equation involves the spatially distributed parameters previously reported.

While vegetation and land use cover can be observed on the ground or by using airplane, the most efficient way to map it is from space. The procedure followed in this study allowed us to derive thematic maps from remotely sensed imagery for 1999 and 2010, adopting NDVI index for assessing vegetation cover changes and unsupervised and supervised image classification for land use maps. These latter are converted into raster layers for input into a GIS to be analyzed and transformed into USLE C-factor. Finally, these maps are combined with the others factors maps to quantitatively evaluate soil erosion risk in this area. The specific objectives were to:

(1) determine the extent and patterns of vegetation and land use changes from 1999 to 2010;

(2) model the probability of soil erosion under the different environmental status;

(3) assess of potential erosion to vegetation and land degradation.

\section{Study Area}

Recently Tangier has been reputed as a major growth area in Morocco and become a vital terrain for economic expansion. As a result, many fields in Tangier suffer from critical environmental issues due to great anthropologic pressure and overexploitation of their resources. In order to evaluate the impact of these changes on the environment specially on land cover and vegetation, Kalaya catchment has been chosen as the study area since it knew a bunch of changes recently, markedly the implementation of Renault-Nissan factory and highway.

The Kalaya watershed is located in the province of Fahs Anjra and Tangier-Assilah, in the Northwestern part of Morocco. It covers an area of approximately $38.37 \mathrm{Km}^{2}$, within $35^{\circ} 38^{\prime}$ to $35^{\circ} 44^{\prime} \mathrm{N}$ latitudes and $5^{\circ} 38^{\prime}$ to $5^{\circ} 47^{\prime} \mathrm{W}$ longitudes (Figure 1).

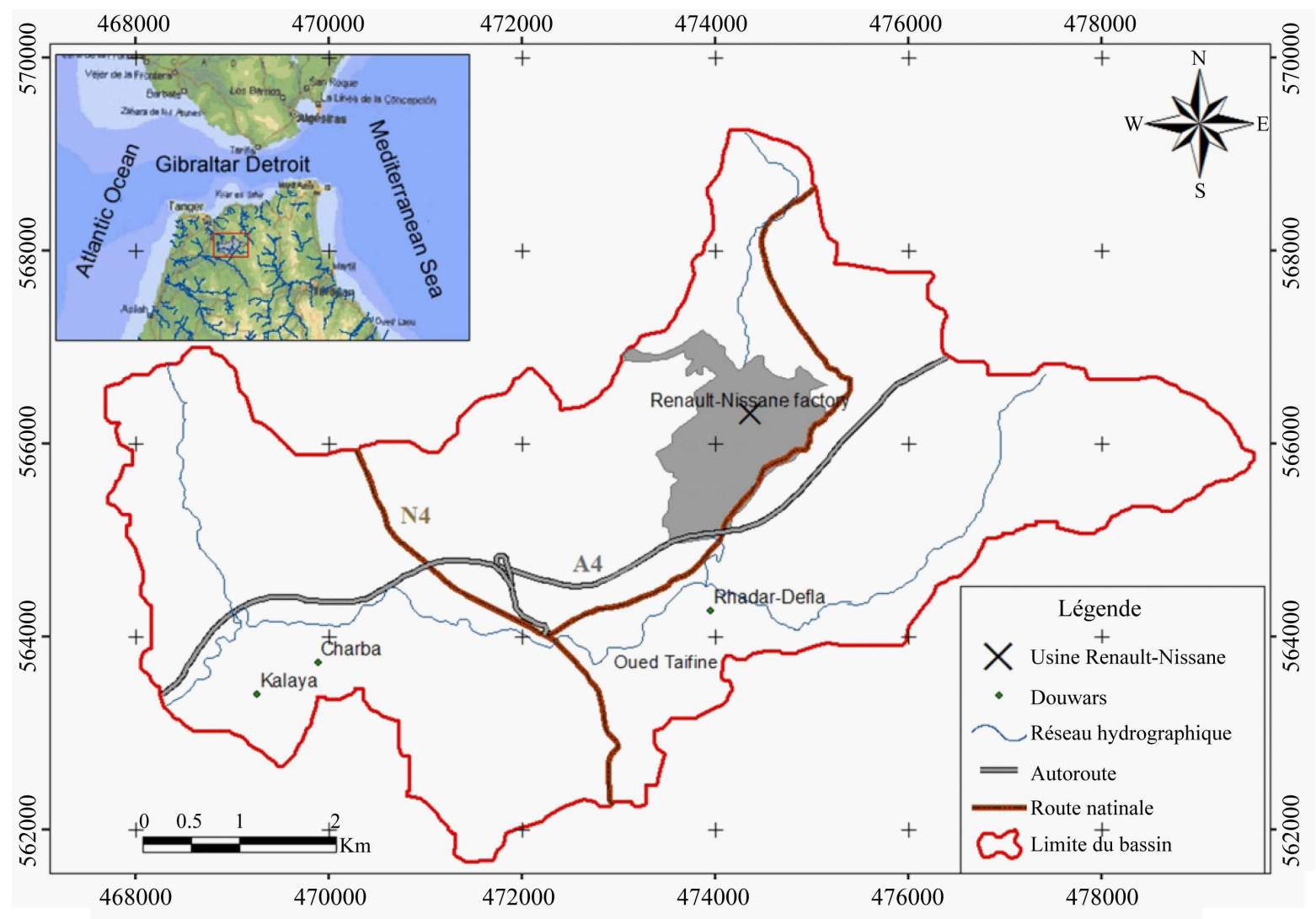

Figure 1. Geographical situation of the Kalaya watershed. 
The present geomorphic configuration of the target watershed is characterized mostly by rolling topography and gentle slopes (slope grades $1 \%$ - 20\%), with an altitude ranges mainly from 27 to $509 \mathrm{~m}$ above sea level (Figure 2). The climate is sub-humid, influenced essentially by the northeast monsoons, with a mean maximum temperature of $25.3^{\circ} \mathrm{C}$ in July, and a minimum one of $11.3^{\circ} \mathrm{C}$ in January. According to the Kalaya and Roumane stations records, the total annual precipitation is $717.6 \mathrm{~mm}$ and 745.4 , respectively.

The Rif chain, which the Kalaya catchment belongs to, is known by mountainous terrain and low plains, with a varied lithology characterized by the presence of marly series and shale. Concerning our study area, the geology is dominated by the Flysch domain which laid on the external unit of Tangier located in the central part of the catchment. These latter are generally formed by clay, pélito-sandstone and flyschs (pélito-sandstone alternations).

As stated in other studies done previously by our research team, the selected site for this work contains various land use types with a predominance of cropland, plowland and urban areas in the majority parts of the watershed, while the upland of the site remains forested.

\section{Material and Methods}

The vegetation cover has a considerable impact in the erosion phenomenon. In fact, the land cover intercepts the rainfall, reduce consequently its energy and increase the infiltration. In this paper we mainly focused on detecting changes, delineating and mapping areas that have witnessed vegetation land changes over 11 year time period (1999-2010) using Landsat imagery and other exogenous data. In addition, we were able to comprehensively analyze the quantitative relationships among plant coverage and soil erosion in the same period applying USLE equation.

\subsection{Data and Tools Used}

Various data types such as topographical maps, satellite images, DEM, Climate data were used to accomplish

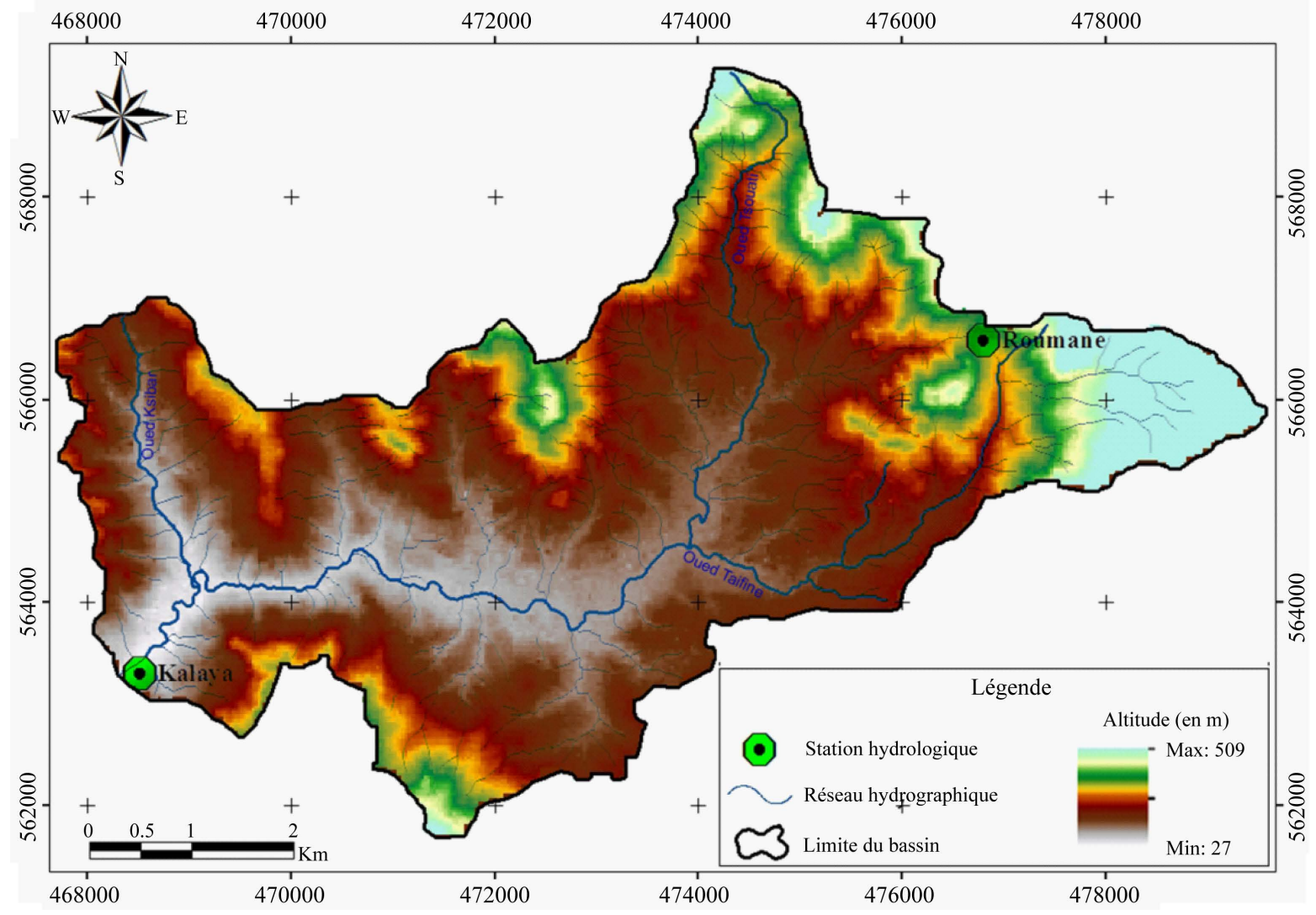

Figure 2. Digital Elevation Model (DEM) of the Kalaya watershed. 
this study and obtain the desired results. Field observations were also conducted to determine land use patterns within the training site. These data and their sources are listed in the Table 1.

\subsection{Methodology}

The time series of vegetation and land use data are from 1999 to 2014 in this paper. Actually, the images used to wetness the vegetation and land use changes are chosen based on the availability and the good quality of the information provided by those images. In a matter of fact, the selected images are free of snow cover and allowed us to interpret diverse types of land use at that time. Digital satellite data from the Landsat TM and ETM+ sensor, with a spatial resolution of 30m acquired in June 2010 and August 1999, respectively, were analyzed to precisely delineate land use boundaries in the study area.

The satellite images were, in first place, ortho-rectified based on multiple ground control points from the topographical maps of the study area. Sufficient ground control points were taken to minimize errors and to get the best results possible. Subsequently, radiometric corrections were applied on the images to achieve means signal variance and remove the effects of changes in satellite sensor.

Considered as one of the most mathematical combinations of satellite bands, the NDVI (Normalized Difference Vegetation Index), was adopted in this research to provide critical information of the presence and the status of the plant coverage well. Accordingly, NDVI is calculated using the follow conventional equation [14]:

$$
\mathrm{NDVI}=\frac{\mathrm{NIR}-\mathrm{R}}{\mathrm{NIR}+\mathrm{R}}
$$

As mentioned above, the calculation of NDVI is based mainly on vegetation behavior that changes from the near-infrared channel (NIR) to the red channel (R). In fact, vegetated areas have high reflectance in the near infrared and low one in the visible red. Water, snow and clouds have larger reflectance in the visual wave than near-infrared wave and bare soil and rocks have similar reflectance in both spectral regions. As a consequence, the best plant's growth conditions are presented by high values for the index, on one side water has negative values and bare soil gives indices around 0 on the other. In between, the others values give an indication for differences in coverage and condition of green vegetation [15].

The next step in this study consists in applying on the images different types of image classification, which can be generally distinguished into unsupervised and supervised classification types. The objective of these latter is to automatically categorize all pixels in an image into land cover classes using different algorithms.

Today several unsupervised classification algorithms are commonly used in remote sensing. The most efficient one is the Iterative Self-Organizing Data Analysis (ISODATA) technique, it allows for different number of clusters while in the other method (K-mean) this number is already fixed. The ISODATA technique uses a maximum likelihood decision rule to calculate class means that are evenly distributed in the data space and then iteratively clusters the remaining pixels, using minimum distance techniques. Each iteration recalculate means and reclassifies pixels with respect to the new means. This process continues until the number of pixels in each class changes by less than a selected [16]. To put it differently, this technique enabled us to create an overall idea on the different classes existing in the area and their distribution.

The acquisition of field observation and data is an essential task to do in order to carry out the supervised classification. Furthermore, ground truth verification were conducted with help of GPS which facilitates the ac-

\begin{tabular}{ccccc} 
Table 1. Data used and their sources. & \multicolumn{3}{c}{} \\
\hline Type & Format & Resolution/scale & Date & Source \\
\hline Landsat TM Image (2010) & Raster & $30 \mathrm{~m}$ & $20 / 06 / 2010$ & Web site GLCF \\
Landsat ETM+ Image (1999) & Raster & $30 \mathrm{~m}$ & $07 / 08 / 1999$ & Web site GLCF \\
Watershed & Shapefile & - & ArcGis \\
DEM ASTER & Raster & $30 \mathrm{~m}$ & Raissouni., 2012 \\
Topographical maps & JPEG & $1 / 50000$ & Google Earth \\
Google Earth imagery & JPEG & - & $06 / 12 / 2013$ & .
\end{tabular}


curacy assessment of supervised classification [17]

The goal set throughout this mission is to identify closely the different types of land uses and collect some soil and vegetation simples for further studies. Moreover, a total of 15 data points were chosen all along the highway and the national road to cover all landscape units. The information collected during the fieldwork was used as guideline for the identification of boundaries between multiple classes.

For the supervised approach, the user has to have a clear idea on how many land cover types exist in the study area. Classification algorithms are used in order to separate the feature space according to the selected training samples designated by ROI (Region Of Interest). The training sets are identified for each land cover class based on previous field knowledge. Therefore, 5 cover classes noticed and chosen for the digital classification of the Kalaya watershed image: Forest, scrub, agriculture land, urban areas, cropland.

Several classification algorithms exist, however, in this study the maximum likelihood technique reply to our aims and gave us the best results possible. Using this technique, image classification was carried out on seven spectral bands and employing the signature files generated from the training areas [18].

In the light of what was mentioned previously, the loss or removal of vegetation cover can result in increased rates of erosion. This cause-effect relationship can be demonstrated convincingly as a result of many studies using multiple physical (ANSWERS, CREAMS, SEMMED...) and empirical (USLE, RUSLE, MUSLE...) methods to estimate erosion rates at the watershed scale [19].

Actually, the Universal Soil Loss Equation (U.S.L.E.), conducted by Wischmeïer et Smith [20]-[24] is known as the empirical model used worldwide to predict soil erosion and with its revised version it introduce advances means to soil erosion factor in order to get the proper precision.

Of these five USLE factors, the cover management factor (C-factor) is an important one affecting soil erosion in a given region, it boost the absorption of the raindrops energy of raindrops, reduce the speed and erosive capacity of runoff, increase the porosity and biodiversity activity in the soil [25]. In fact, studies conducted previously by researchers has revealed that the main factor that controls the spatial distribution of the erosion is the type of vegetation cover and it is affected, specifically, by the variability of winter foliage loss [26]. However, modeling the C-factor is considered as a challenging task for complex terrain. The C-factor in the soil loss equation is defined as the ratio of soil loss from land cropped under specified conditions to the corresponding loss from clean-tilled, continuous fallow [27]. Land use classification is often used to map vegetation types that differ in their effectiveness to protect the soil. After the previous classification, C-factors are assigned according to a qualitative ranking of vegetation types [28]. Otherwise the proportional vegetation cover varied widely even for the same vegetation type [29]. Land cover maps obtained previously were converted into a C-factor maps as mentioned in the diagram below (Figure 3). Notably, the C-factors values for the different land cover types were obtained from literature [28].

All the factor maps of USLE equation, provided by a study conducted by our research team in the same study area, except $\mathrm{C}$ factor that was generated from our land use maps, were integrated in GIS frame to generate a composite map of erosion showing the amount of soil loss in the study area. The soil loss (A) due to water erosion (t/ha/year) was quantified using the USLE expressed as follows [30]:

$$
A=R \times K \times L \times S \times C \times P
$$

With

$$
\begin{aligned}
& A=\text { soil loss in } \mathrm{t} / \mathrm{ha} / \text { year } \\
& R=\text { rainfall erosivity factor in } \mathrm{MJ} \cdot \mathrm{mm} \cdot \mathrm{ha}^{-1} \cdot \mathrm{H}^{-1} \cdot \mathrm{year}^{-1} \\
& K=\text { soil erodibility factor in } \mathrm{t} \cdot \mathrm{ha} \cdot \mathrm{H} \cdot \mathrm{ha}^{-1} \cdot \mathrm{MJ}^{-1} \cdot \mathrm{mm}^{-1} \\
& L=\text { slope length in } \mathrm{m} \\
& S=\text { slope steepness in } \% \\
& C=\text { vegetation cover factor or land use factor } \\
& P=\text { erosion control practices factor. }
\end{aligned}
$$

\section{Results}

The approach designated in this study to map vegetation cover and land use changes has successfully generate serviceable maps used to discern relationship between soil loss and land use. Figure 4 and Figure 5 are the NDVI maps for 1999 and 2010 respectively; they show the distribution of NDVI values in Kalaya catchment 


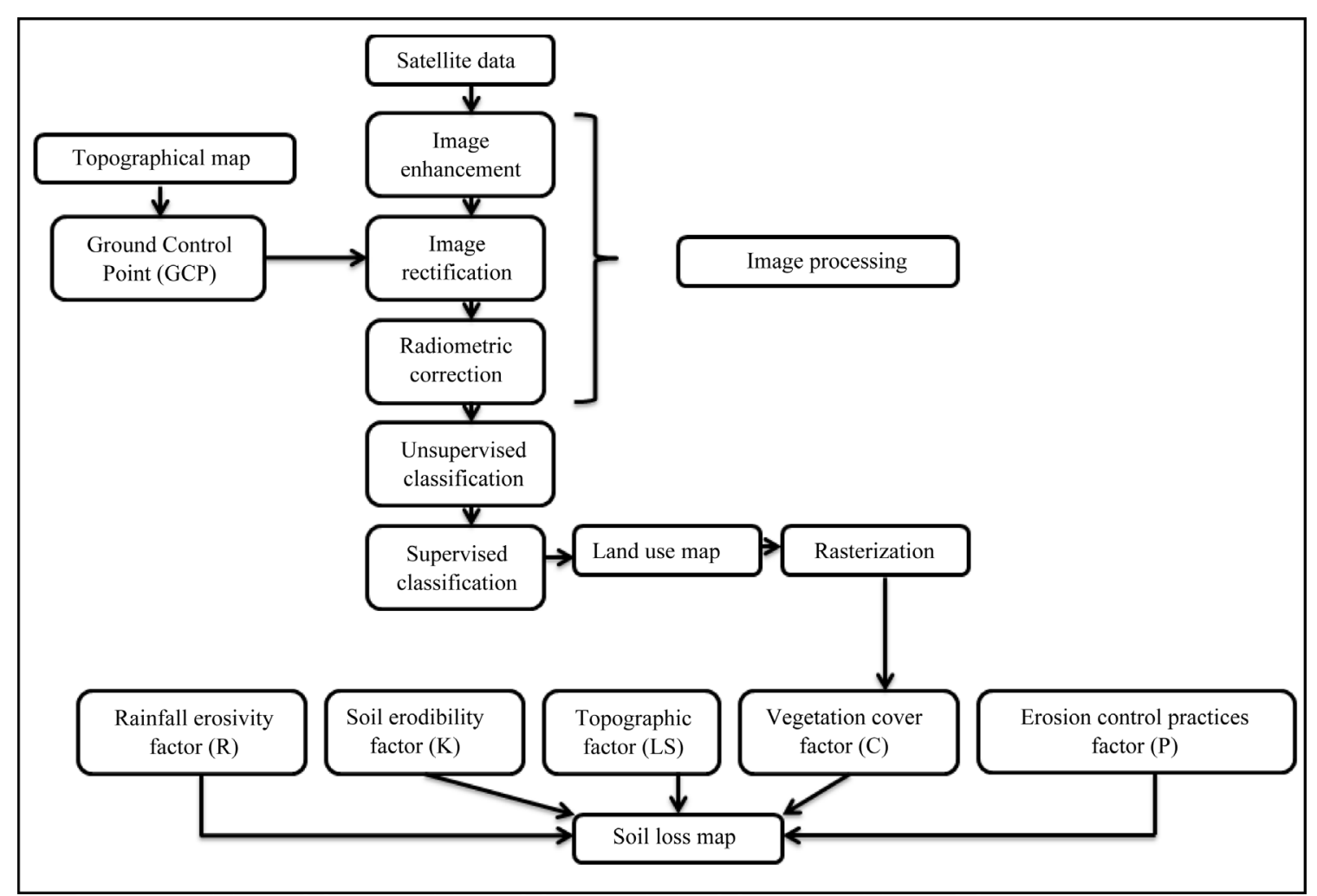

Figure 3. Diagram of the methodology used mapping land use and modeling soil loss in Kalaya watershed.

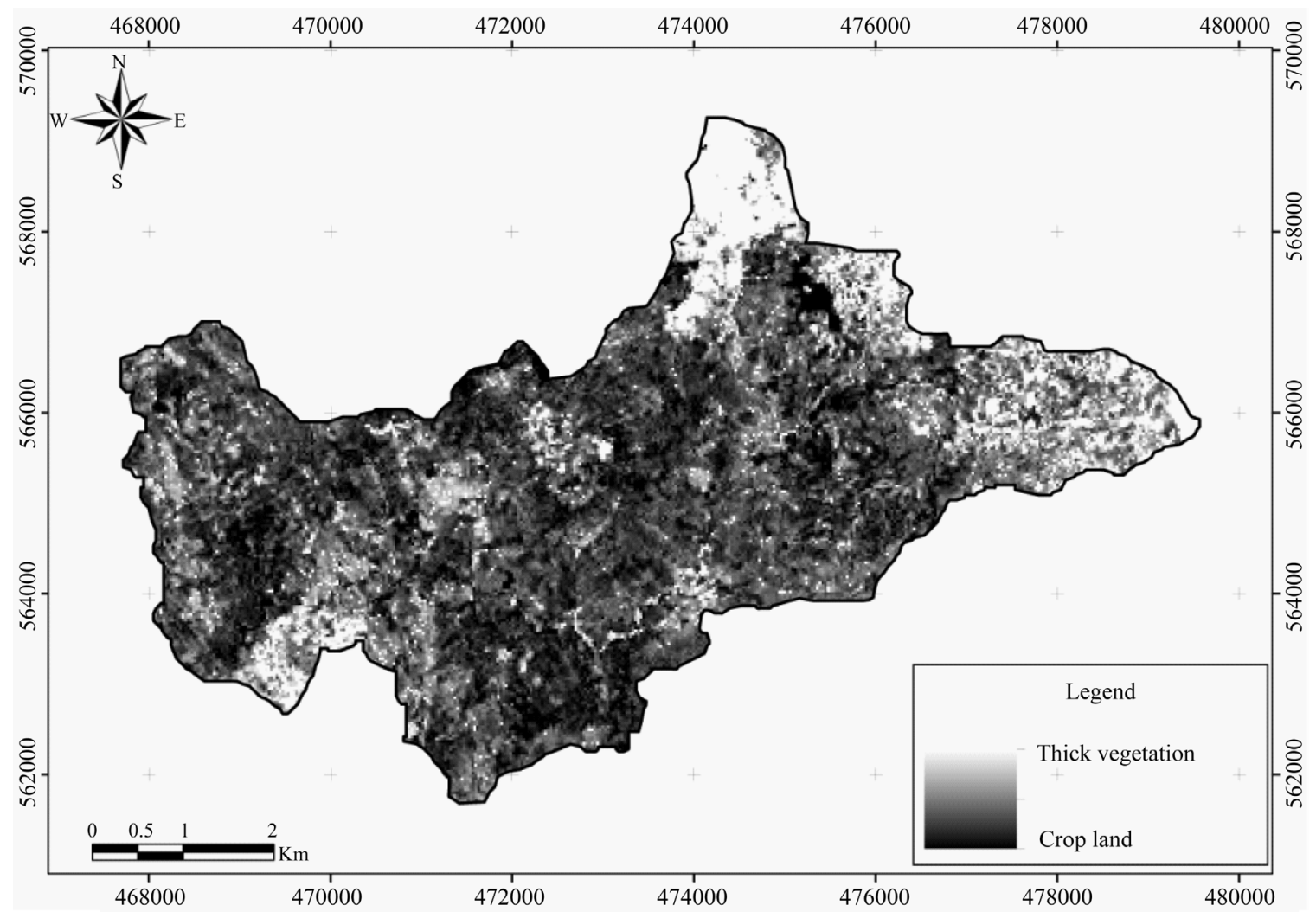

Figure 4. NDVI map of the Kalaya Watershed in 1999. 


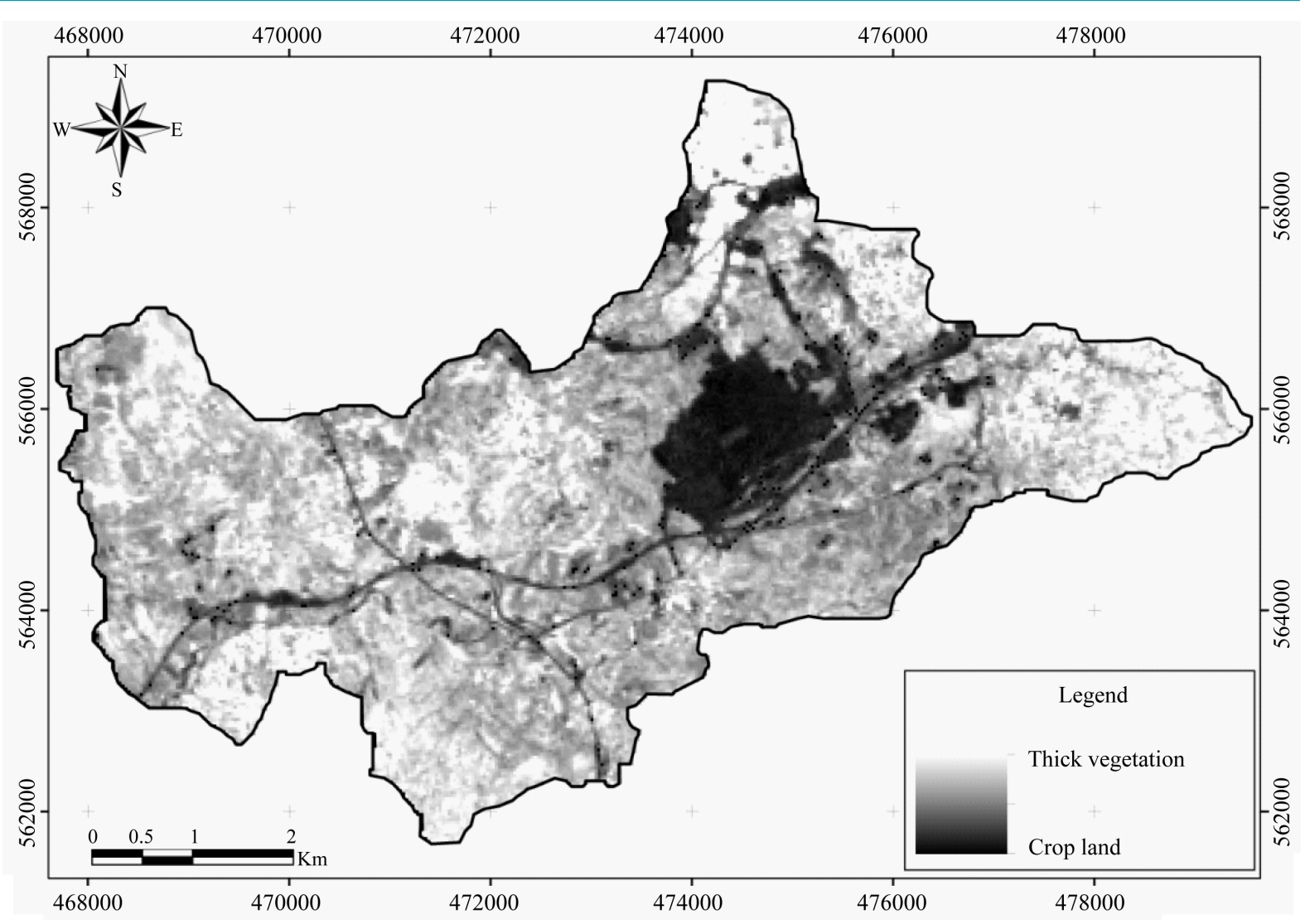

Figure 5. NDVI map of the Kalaya Watershed in 2010.

during the period time of this study. Comparing between the 2 figures, we noticed that the maximum value of NDVI index in 2010 (0.59) is higher than the one calculated in 1999 (0.48). We can notice from the figures decreasing trends in vegetation cover distribution with the progression of time. Accordingly, the areas occupied by forest has become smaller and a larger part of the watershed has been detained to human activities purpose.

With in mind to confirm and approve the results obtained and observed from the NDVI maps, imagery unsupervised classification was carried out and two maps were obtained (Figure 6 and Figure 7) presenting the land use maps in 1999 and 2010 respectively, in the study area. Analyzing the 1999 land use map, we noticed a large proportion of scrub and small one of crop land. Unlikely, the unsupervised classification for 1999 imagery ceases the area in only 4 units. Meanwhile, in 2010 land use map we have all the 5 units desired mapped with a decrease in the area of forest, scrub, crop land at the expense of agriculture land and urban areas.

Satellite images were then subjected to a treatment in Envi using, this time, supervised classification, which furnished pleasing results and provided highly accurate maps (Figure 8 and Figure 9).

A comparison of land use classes in 1999 vs. 2010 has shown that in 2010 urban areas govern the land use types in the catchment as a result of the economic expansion. Likewise, with the growth of the human activities in the areas the superficies of agriculture lands increase from $5.25 \mathrm{~km}^{2}$ in 1999 to 11.46 in 2010 (Table 2). Otherwise, the land use for scrub and forest in 2010 greatly declined leaving space for urban areas. Classification of land use had an overall accuracy of $91.1712 \%$, which can be considered as an excellent accurate classification of satellite images with Kappa index of 0.8830 .

The main result of the application of USLE model is soil loss maps, these latter were divided into 11 classes to ensure easy distinction between areas with different levels of risk erosion and better visualization of results. In our case we have generated two maps presented in Figure 10, the first one shows soil loss rate in 1999 and the second one in 2010. From the first sight, we recognized that erosion loss in the study area ranges among 30 $\mathrm{T} / \mathrm{h} / \mathrm{yr}$, the lower values are placed in the northern extreme part, while the higher ones are spread all over the whole watershed. 
K. Ben Hamman Lech-hab et al.

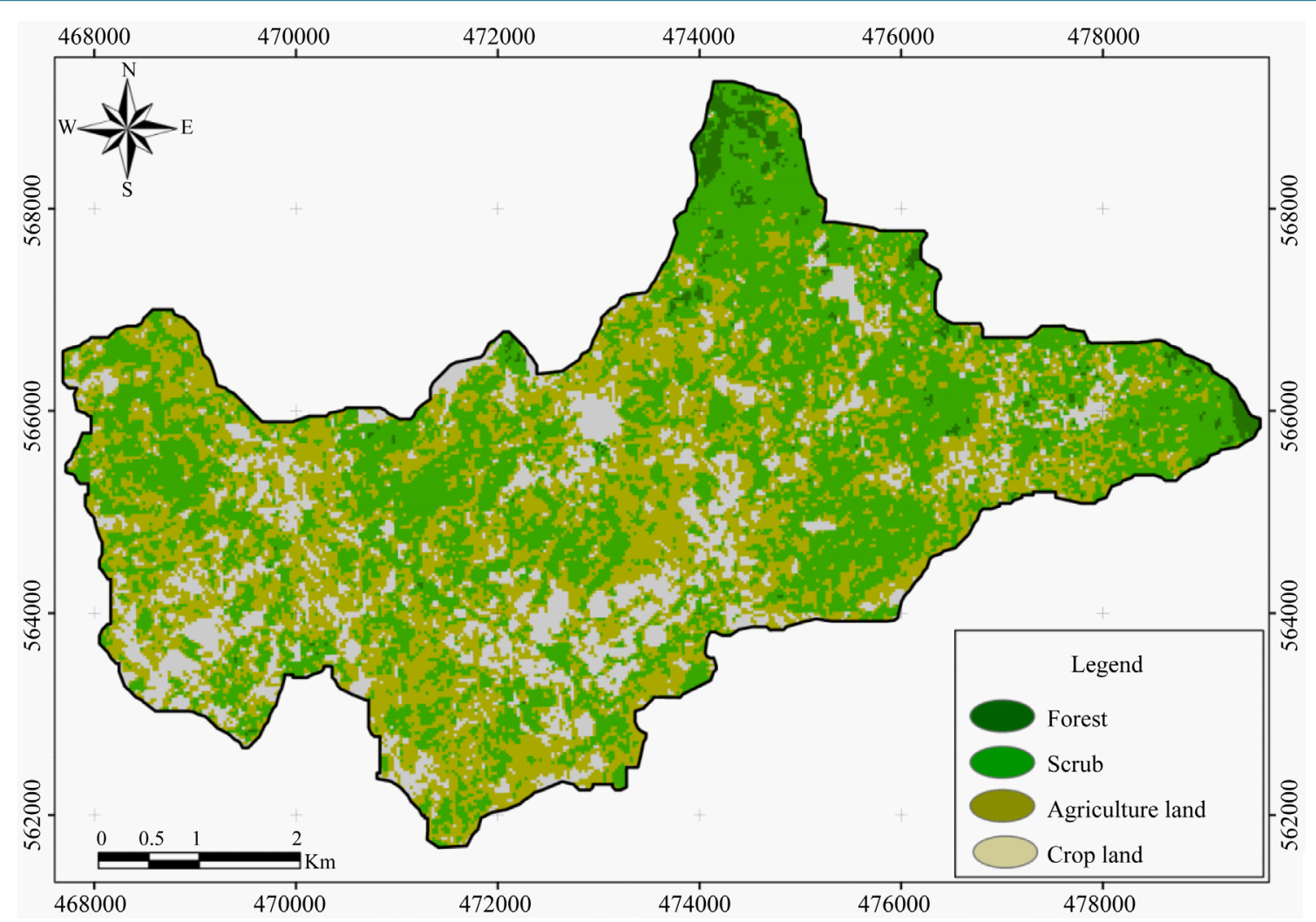

Figure 6. Land use map of the Kalaya watershed in 1999 using unsupervised classification.

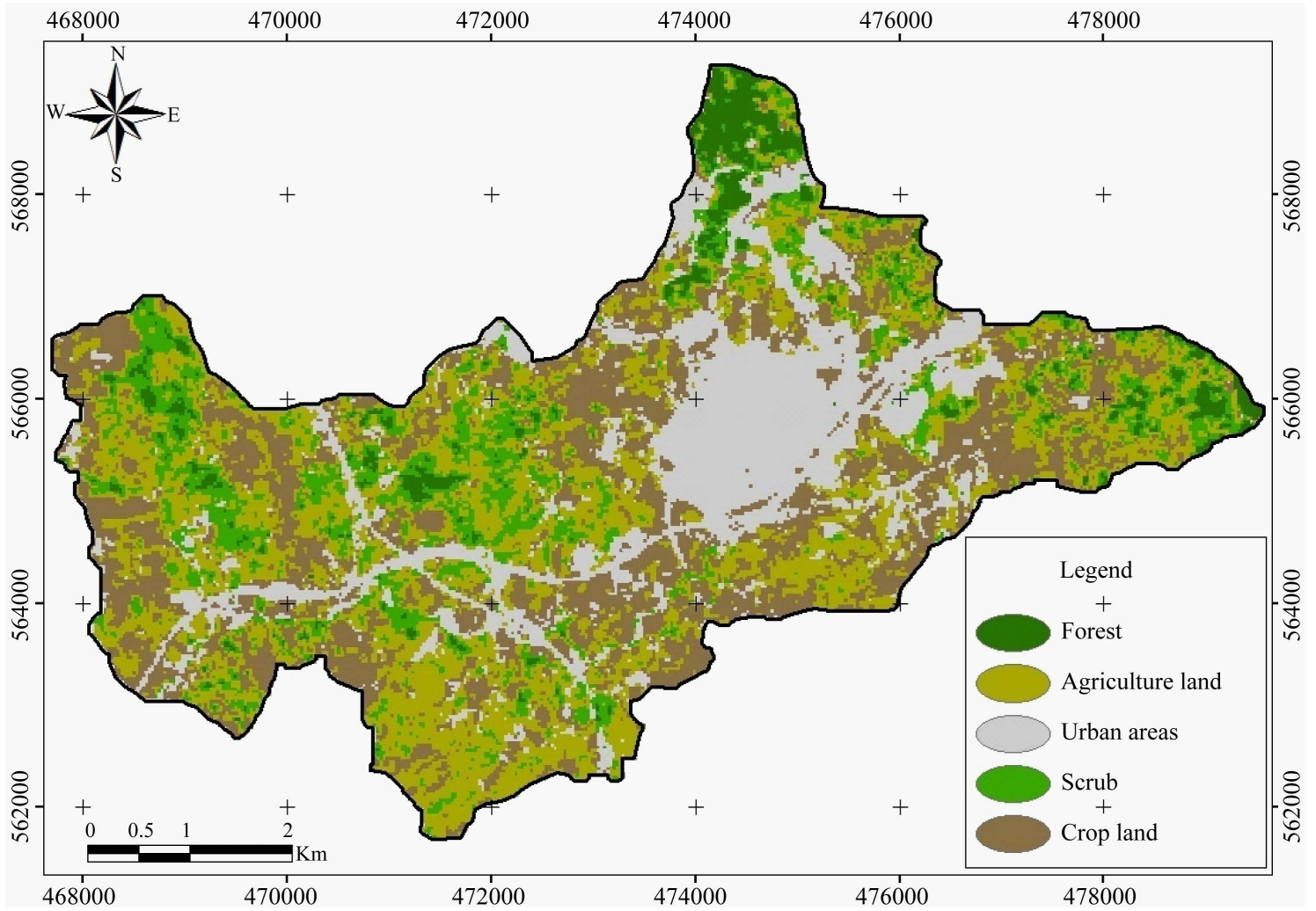

Figure 7. Land use map of the Kalaya watershed in 2010 using unsupervised classification. 


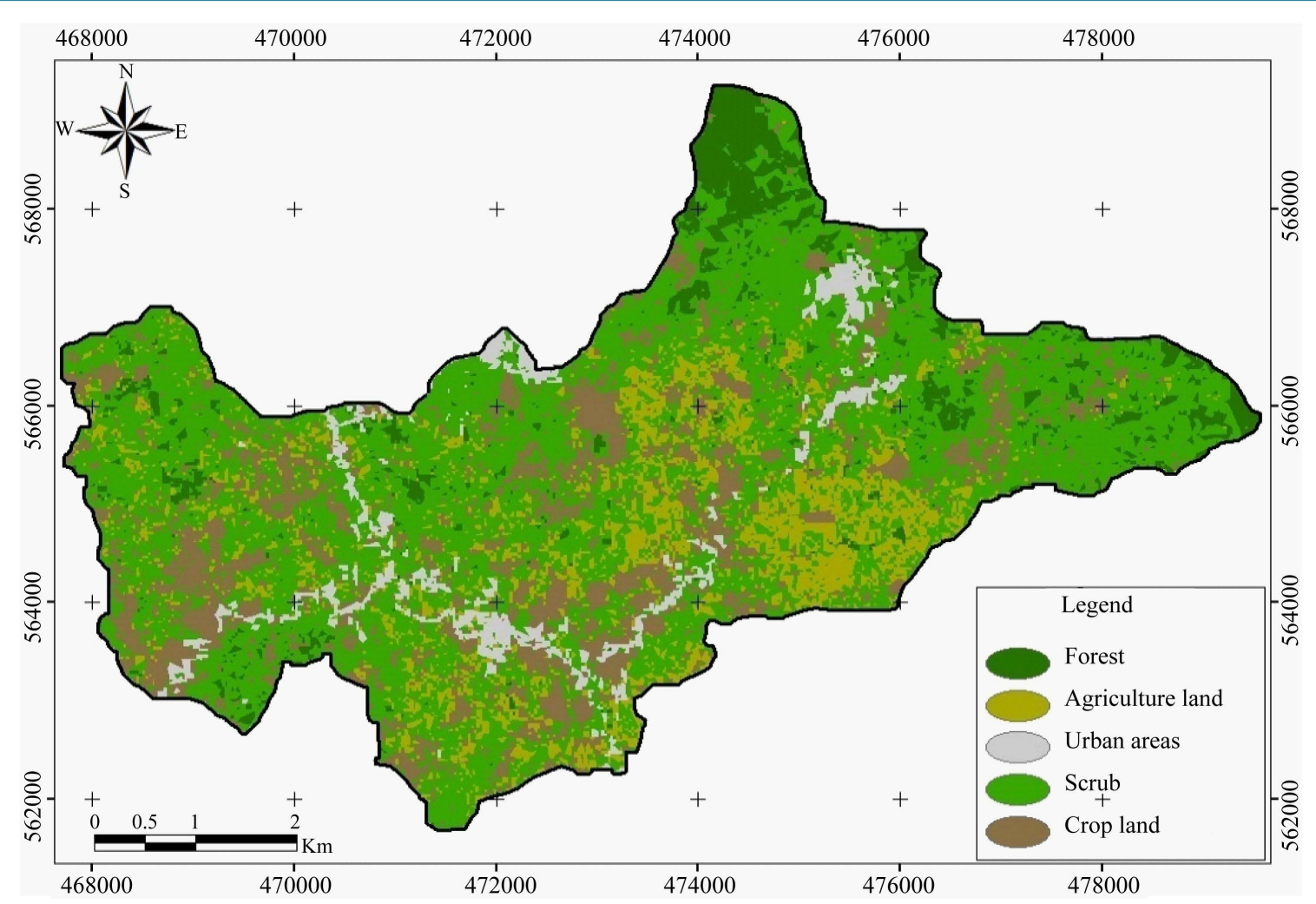

Figure 8. Land use map of the Kalaya watershed in 1999 using supervised classification.

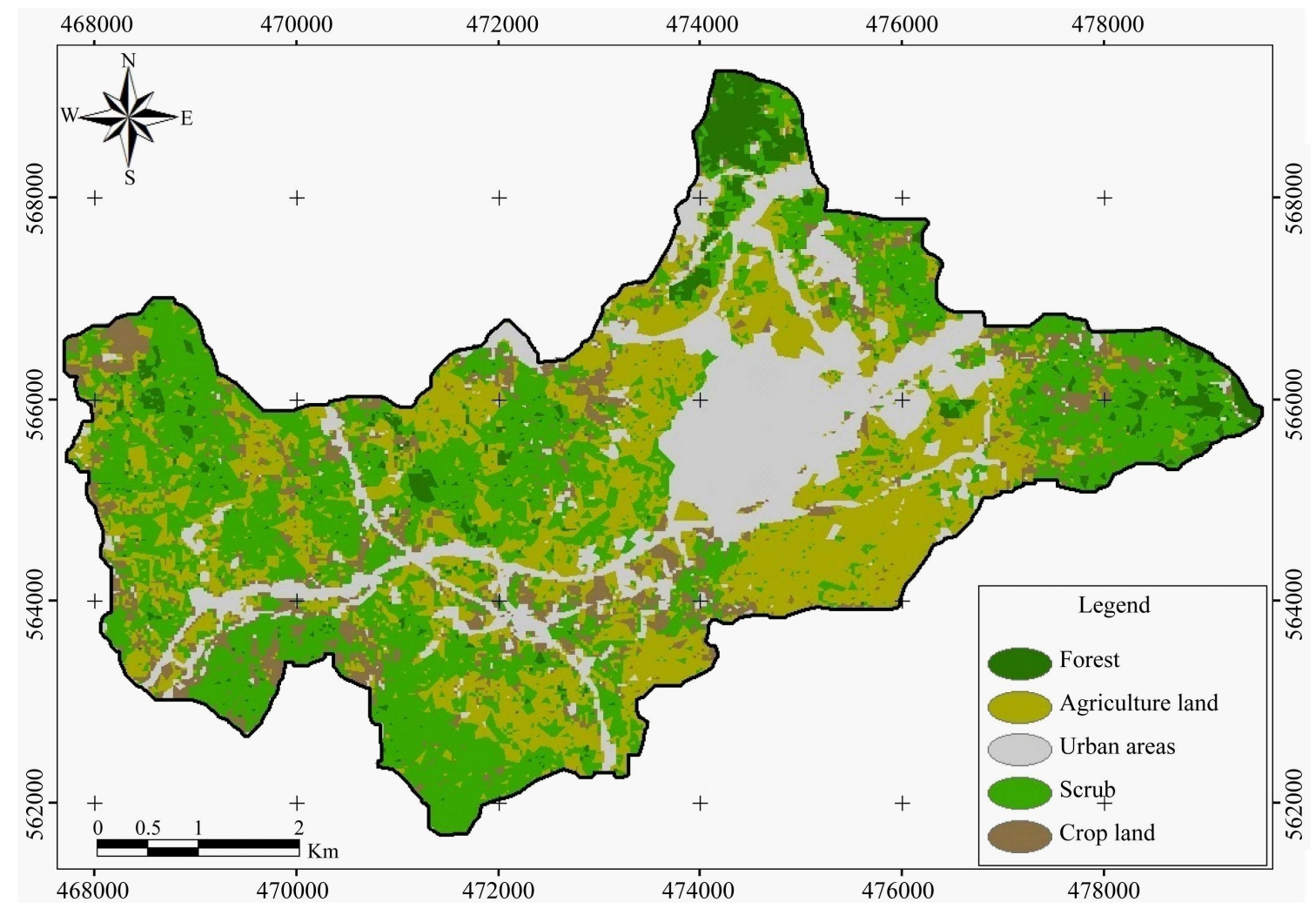

Figure 9. Land use map of the Kalaya watershed in 2010 using supervised classification. 
Table 2. Superficies and coverage of each land use types during the study period.

\begin{tabular}{|c|c|c|c|c|}
\hline \multirow{2}{*}{ Land use types } & \multicolumn{2}{|c|}{ Land use in 2010} & \multicolumn{2}{|c|}{ Land use in 1999} \\
\hline & Superficies in $\mathrm{Km}^{2}$ & Percentage & Superficies in $\mathrm{Km}^{2}$ & Percentage \\
\hline Forest & 1.75 & 4.56 & 2.85 & 7.43 \\
\hline Scrub & 14.2 & 37.01 & 21.29 & 55.49 \\
\hline Agriculture land & 11.46 & 29.87 & 5.25 & 13.68 \\
\hline Crop land & 3.42 & 8.91 & 7.01 & 18.27 \\
\hline Urban areas & 7.54 & 19.65 & 1.97 & 5.13 \\
\hline Total & 38.37 & $100 \%$ & 38.37 & $100 \%$ \\
\hline
\end{tabular}

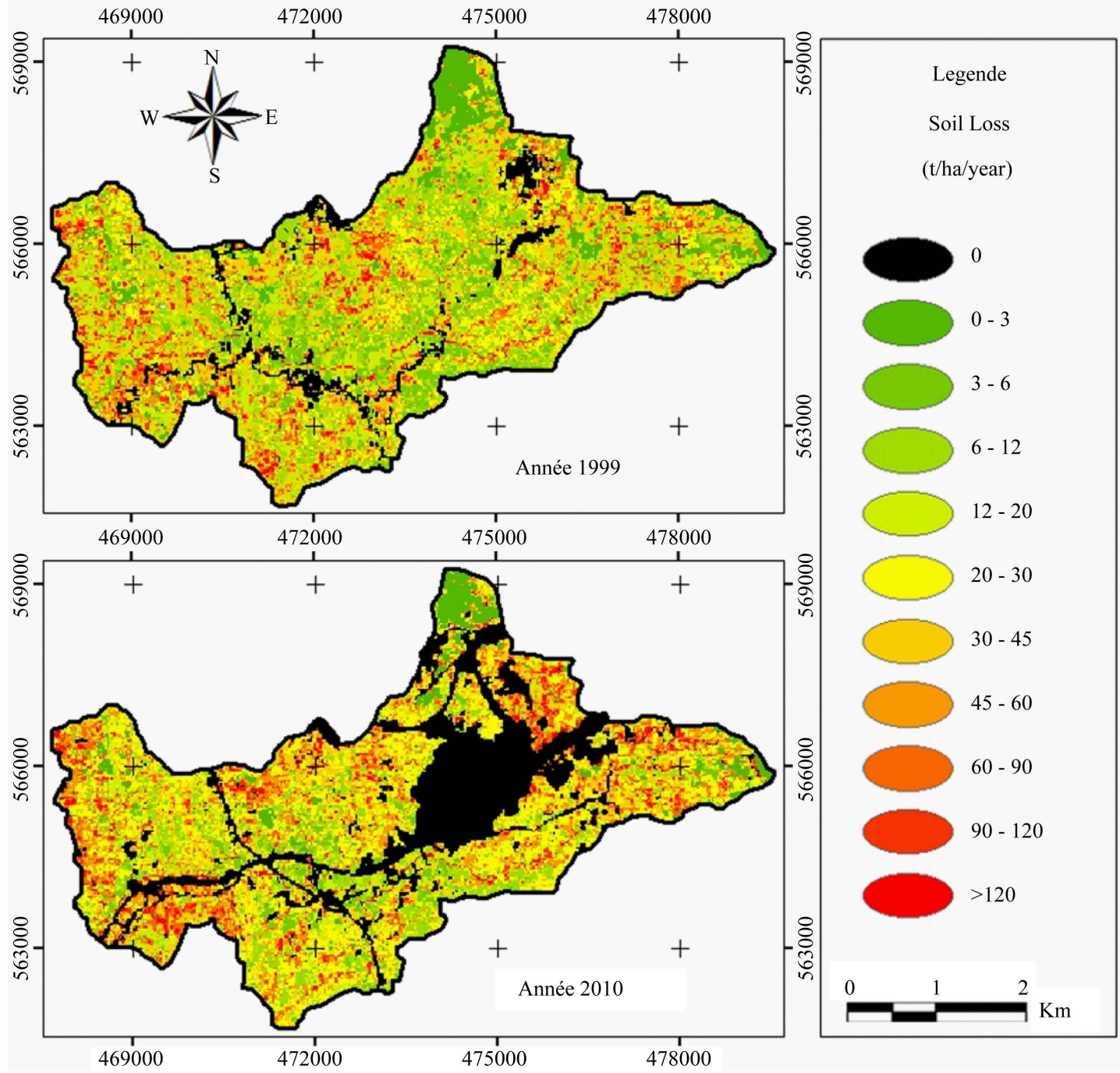

Figure 10. Erosion risk map in Kalaya watershed in 1999 and 2010.

\section{Discussion}

The diachronic assessment of vegetation cover and land use helped restore the changes that has suffered the study area recently. NDVI maps have revealed a variation of vegetation cover during the 11 years of study. The 
values calculated for the two dates are close and reach 0.48 for the forest in 1999 and 0.51 in 2010.

The comparison between multidate maps emphasizes the enormous impact of the installation of Renault factory and highway. Unfortunately the application of unsupervised method has not given specific results for 1999 as it has combined the urban areas and crop land into one class. Changes in vegetation cover are more evident on maps provided by the supervised classification than the others.

The watershed was composed of five land use types, which were crop land (8.91\% in 2010 and $18.27 \%$ in 1999), urban areas (19.65\% in 2010 and 5.13\% in 1999), agriculture land (29.87\% in 2010 and $13.68 \%$ in 1999$)$, scrub (37.01\% in 2010 and 55.49\% in 1999), and forest (4.56\% in 2010 and 7.43 in 1999), having the USLE-C values of $0.14,1,0.1,0.05$ and 0.001 , respectively. Accordingly, the scrub and forest have known a decrease while the urban and agriculture areas have enormously increases.

The results have reached the level of satisfaction desired. With a Kappa coefficient of 0.88, land use map obtained in 2010 is in harmony with the results of the ground truth.

In a matter of fact, the current economic and environmental situation of our study area doesn't reflect the right development and preservation of vegetation cover, perceived by regression and reduction of dense vegetation in general. Therefore, this contraction exposes more soil to water erosion agents namely runoff and precipitation. Accordingly, the areas covered forest and scrub have lowest values of soil loss which make them less affected by soil erosion while crop lands and agriculture lands are the more threaten by soil erosion and represent the highest values of soil loss. Most of the high-risk areas had significant less vegetation cover than did areas at lower risk for erosion. The results of assessing soil loss during the study period revealed an increase in the average risk of erosion of $31.68 \mathrm{t}$ /ha/year in 1999 to $34.74 \mathrm{t} /$ ha/year in 2010.

The USLE model has provided useful understanding of soil degradation at watershed scale and its relationship with the changes occurred in the land use during the time of this study. However, there is a need to apply other models, execute experimental plots, increase the number of UH for $\mathrm{K}$ values more detailed for a better prediction of erosion risk in the area. Therefore, future works are required for monitoring of sediment, precipitation.

As a total, changes in the distribution of vegetation cover and land use showed a negative impact on soil erosion, leading soil loss rates to higher values. The most effective vegetation cover against soil loss and runoff is forest followed by Scrub. Accordingly, converting forest and Scrub into agriculture lands and crop lands contributed to substantial runoff and greatly accelerated soil losses.

Therefore, erosion control practices are required in this case especially in vulnerable areas of Kalaya watershed on a priority basis to reduce the amount of the annual soil loss by protecting major infrastructure, anticipate related risks such as mudslides, landslides, floods created by the clogging of sediment in streams, silting of water reservoirs along with others phenomenon. This study revealed that the vegetation cover and land use could efficiently protect soil against erosion loss. Good plant cover is capable of preventing soil erosion and reducing landslides as well and removing it can greatly increase soil erosion

Existing studies have shown and proved the positive and the effective impact of the vegetation cover reflected by the $C$ factor on soil erosion. In like manner, [31] [32] in their study about the variation of vegetation cover in Tleta watershed has show that this latter is experiencing a permanent degradation, probably as a result of clearing, overgrazing and excessive exploitation by the population and thereby expose the soil to water erosion. Implementing soil conservation measures in high-risk areas not only increases the effectiveness of reducing soil loss, but also of reducing the cost of soil conservation.

To summarize, the relationships between soil loss and land use/vegetation cover in its various states were significant. Thus, forests followed by scrub were more effective in reducing soil erosion than agriculture lands.

\section{Conclusions}

This study emphasis the constructive and useful function of USLE model, Remotely Sensed data and the GIS system as well in modeling and assessing vegetation cover and it influence on erosion phenomenon water erosion in considerable short time and low cost for large watersheds.

The selected methodology was efficient and provided good confidences in simulating and mapping vegetation and land use degradation along with soil erosion risk. However, we should incorporate more supporting data, target vulnerable areas and create scenarios of erosion control practices.

According to the results obtained, the vegetation cover has decreased leaving space to urban areas and agriculture lands. The overall estimated soil erosion rate in the study area increased from $31.68 \mathrm{t} / \mathrm{ha} / \mathrm{yr}$ to 34.74 
t/ha/yr. The high soil loss rates observed for the whole watershed and during the time, comparing with the tolerance value usually accepted, suggest that soil erosion is straightly influenced by the land use types existing in the watershed.

After the work done among this study we concluded that vegetation cover degradation and soil erosion risk have remarkably increased recently and it have resulted from the economic expansion. At least, some effective measures with good grounds for soil conservation must be applied to improve the ecological environment in the watershed. After the work done among this study we concluded that vegetation cover degradation and soil erosion risk have remarkably increased recently and it have resulted from the economic expansion. At least, some effective measures with good grounds for soil conservation must be applied to improve the ecological environment in the watershed. Furthermore, the results and data presented in this work have the advantage of being easily accessible, updatable.

\section{References}

[1] Food and Agriculture Organization (FAO) (1997) State of the World's Forests. Forestry Department, Words and Publications Eds, Oxford, UK. http://www.fao.org/docrep/w4345e/w4345e00.HTM

[2] Food and Agriculture Organization/United Nations Environmental Programmed (FAO/UNEP) (1999) Terminology for Integrated Resources Planning and Management. In: Choudhury, K. and Jansen, L. J.M., Eds. https://www.mpl.ird.fr/crea/taller-colombia/FAO/AGLL/pdfdocs/landglos.pdf

[3] Floras, S. and Sgouras, L.D. (1999) Use of Geoinformation Techniques in Identifying and Mapping Areas of Erosion in a Hilly Landscape of Central Greece. International Journal of Applied Earth Observations and Geoinformation, 1, 68-77. http://dx.doi.org/10.1016/S0303-2434(99)85030-2

[4] Agrell, P.J., Stam, A. and Fischer, G.W. (2004) Interactive Multiobjective Agro-Ecological Land Use Planning: The Bungoma Region in Kenya. European Journal of Operational Research, 158, 194-217. http://dx.doi.org/10.1016/S0377-2217(03)00355-2

[5] Alemayehua, F., Tahaa, N., Nyssenc, J., Girmaa, A., Zenebea, A., Behailua, M., Deckersd, S. and Poesen, J. (2009) The Impacts of Watershed Management on Land Use and Land Cover Dynamics in Eastern Tigray. Resources, Conservation and Recycling, 53, 192-198. http://dx.doi.org/10.1016/j.resconrec.2008.11.007

[6] Rey, F., Ballais, J. L., Marre, A. and Rovéra, G. (2004) Role of Vegetation in Protecting against Surface Water Erosion [Rôle de la végétation dans la protection contre l'érosion hydrique de surface]. Comptes Rendus Geoscience, 336, 991-998. http://dx.doi.org/10.1016/j.crte.2004.03.012

[7] Blavet, D., De Noni, G., Le Bissonnais, Y., Leonard, M., Maillo, L., Laurent, J.Y., Asseline, J., Leprun, J.C., Arshad, M.A. and Roose, E. (2009) Effect of Land Use and Management on the Early Stages of Soil Water. Soil \& Tillage Research, 106, 124-136. http://dx.doi.org/10.1016/j.still.2009.04.010

[8] De Noni, G., Laurent, J. and Ambert, E. (2002) The Study of Erosion and Erosion Control in Morocco Guided through a Partial Bibliographic Review [L'étude de l'érosion et de la lutte antiérosive au Maroc commentée au moyen d'une revue bibliographique partielle]. Erosion Network Bulletin, 21, 448-469. http://www.documentation.ird.fr/hor/fdi:010031044

[9] De Ploey, J., Imeson, A. and Oldeman, L.R. (1991) Soil Erosion, Soil Degradation and Climatic Change. In: Brouwer F.M., Thomas A.J. and Chadwick, M.J., Eds., Land Use Changes in Europe, Volume 18 of the Series The GeoJournal Library, 275-292. http://dx.doi.org/10.1007/978-94-011-3290-9_12

[10] Elyousfi, SM. and M'Hirit, O. (1998) Conservation and Use of Moroccan Forest Genetic Resources: Provenance Regions [La conservation et l'utilisation des ressources génétiques forestières marocaines: Les régions de provenances]. In: Bani-Aameur, F., Ed., Argan and Plants in Arid and Semi-Arid. International Symposium on Plant Resources [L'arganier et les plantes des zones arides et semi-arides. Colloque international sur les ressources végétales], 23-25 April 1998, Agadir, 8, 11.

[11] Dagan, R., Boughlala, M., Mrabet, R., Laamari, A., Balaghi, R. and Lajouad, L. (2012) A Review of Available Knowledge on Land Degradation in Morocco. International Center for Agriculture Research in the Dry Areas (ICARDA). http://www.icarda.org/publication/working-papers

[12] FAO (Food and Agriculture Organization) (1977) Assessing Soil Degradation. FAO Soil Bulletin, 34, 83 p. http://www.fao.org/3/a-ar114e.pdf

[13] FAO (1990) Soil and Water Conservation in Semi-Arid Areas [Conservation des sols et des eaux dans les zones semi-arides]. Fao Soils Bulletin, 57, 182 p. http://horizon.documentation.ird.fr/exl-doc/pleins_textes/divers15-05/39357.pdf

[14] Xin, X.Y., Xue, X.Z., Jian, L.L., Man, L.Z. and Yuan, Y.X. (2006) Effects of Vegetation Cover and Precipitation on 
the Process of Sediment Produced by Erosion in a Small Watershed of Loess Region. Acta Ecologica Sinica, 26, 1-8. http://dx.doi.org/10.1016/S1872-2032(06)60001-2

[15] Erencin, Z. (2000) C-Factor Mapping Using Remote Sensing and GIS. A Case Study of Lom Sak Lom Kao, Thailand. International Institute for Aerospace Survey and Earth Sciences (ITC), Enschede/Holland, Justus-Liebig-Universität Giessen, 28 p.

[16] Berken, U. (2008) Soil Erosion Modelling by Using GIS and Remote Sensing: A Case Study. The International Archives of the Photogrammetry, Remote Sensing and Spatial Information Sciences, Vol. XXXVII, Part B7, 1681-1684.

[17] Rajitha, K., Mukherjee, C.K. and Vinu Chandran, R. (2007) Applications of Remote Sensing and GIS for Sustainable Management of Shrimp Culture in India. Aquacultural Engineering, 36, 1-17. http://dx.doi.org/10.1016/j.aquaeng.2006.05.003

[18] Baja, S., Ramli, M. and Lias, S.A. (2009) Spatial-Based Assessment of Land Use, Soil Erosion, and Water Protection in the Jeneberang Valley, Indonesia. Biologia, 64, 522-526. http://dx.doi.org/10.2478/s11756-009-0074-y

[19] Khali Issa, L., Raissouni, A., El Arrim, A. and Moussadek, R. (2014) Mapping and Assessment of Water Erosion in the Khmiss Watershed (North Western Rif, Morocco). Journal of Current Advances in Environmental Sciences, 2, 119130.

[20] Wischmeïer, W.H. (1958) Rainfall Energy and Its Re1ationship to Soi1 Loss. American Geophysical Union, 39, 285-291. http://dx.doi.org/10.1029/TR039i002p00285

[21] Wischmeier, W.H. (1959) A Rainfall Erosion Index for a Universal Soil-Loss Equation. Soil Science Society of America Proceedings, 23, 246-249. http://dx.doi.org/10.2136/sssaj1959.03615995002300030027x

[22] Wischmeier, W.H. and Smith, D.D. (1960) A Universal Soil Loss Estimation Equation to Guide Conservation Farm Planning. 7th Inter. Cong. Soil Sci, Vol. 1, Madison, 418-425.

[23] Wischmeier, W.H. and Smith, D.D. (1965) Prediction Rainfall Erosion Losses from Cropland East of the Rocky Mountains: A Guide for Selection of Practices for Soil and Water Conservation. Agricultural Handbook, No. 282, 47 p.

[24] Wischmeier, W.H. and Smith, D.D. (1978) Predicting Rainfall Erosion Losses: A Guide to Conservation Planning. Agricultural Handbook, No. 537, 58 p. http://naldc.nal.usda.gov/download/CAT79706928/PDF

[25] Alexandridis, T.K., Sotiropoulou, A.M., Bilas, G., Karapetsas, N. and Silleos, N.G. (2013) The Effects of Seasonality in Estimating the C-Factor of Soil Erosion Studies. Land Degradation and Development, 26, 596-603. http://dx.doi.org/10.1002/ldr.2223

[26] Menashe, E. (2006) Vegetation and Erosion. Greenbelt Consulting. Environmental Education Assessment \& Management. http://www.wnps.org/landscaping/documents/slope stabilizing plants.pdf

[27] Zhou, P., Luukkanen, O., Tokola, T. and Nieminen, J. (2008) Effect of Vegetation Cover on Soil Erosion in a Mountainous Watershed. Catena, 75, 319-325. http://dx.doi.org/10.1016/j.catena.2008.07.010

[28] Raissouni, A. (2012) Modeling and Mapping of Sensitivity and Soil Erosion Risk at Regional Scale by GIS and USLE (North Western Rif, Morocco) [Modélisation et cartographie de la sensibilité et de l'aléa d'érosion des sols à l'échelle régionale par SIG et USLE (Rif Nord occidental, Maroc)]. Ph.D. Thesis, Faculty of Sciences and Techniques of Tangier, Morocco.

[29] Khali Issa, L., Raissouni, A., El Arrim, A. and Moussadek, R. (2014) Application of SIG-USLE Approach for Mapping and Modeling Soil Loss Bni Hlou watershed (Western North of Morocco) [Application d'une approche SIG-USLE pour la cartographie et la modélisation des pertes de sol au niveau du bassin versant de l'oued Bni Hlou (Nord Ouest du Maroc)]. ScienceLib, 6, No. 140601.

[30] Renard, K.G., Foster, G.R., Weesies, G.A., McCool, D.K. and Yoder, D.C. (1997) Predicting Soil Erosion by Water: A Guide to Conservation Planning with the Revised Universal Soil Loss Equation (RUSLE). USDA-Agriculture Handbook, No. 703.

[31] El Haddad, M. (1993) Studying and Mapping Land Cover of BV Tleta: Using SPOT HRV Data, Aerial Photography and GIS [Etude et cartographie du couvert végétal du B.V. de Tleta: Utilisation des données SPOT HRV, des photographies aériennes et d'un S.I.G.]. 3rd Cycle, Agronomic and Veterinary Institute Hassan II.

[32] Hammouda, N. (2010) Evolution of Land Use and Erosion in the Watershed Tleta (Morocco Rif Occidental-) [Evolution de l'occupation des sols et de l'érosion dans le bassin versant Tleta (Rif Occidental-Maroc)]. 3rd Cycle, Agronomic and Veterinary Institute Hassan II. 